\title{
VIOLENCE: THE MALIGNANCY OF OUR TIMES! IS THERE HOPE?
}

\section{Elissa P. Benedek}

I am truly honored to be here with you tonight and to remember Karen Horney. It's hard to believe that 50 years have gone by since Karen Horney founded the American Institute for Psychoanalysis and the Association for the Advancement of Psychoanalysis. Her contributions to the field of analysis and psychiatry have survived the test of time, forming a link between the old school of pure psychoanalytic thought and today's biopsychosocial approach to the treatment of psychiatric patients. Horney said, "Man turns uncontrollable or destructive only if he cannot fulfill himself." Fifty years ago was she clairvoyant? Could she envision the horror of the Los Angeles riots, the assassination of presidents? Did she foresee private citizens packing guns as they went to work? Those who knew Horney best did not find it difficult to account for her clairvoyance and her foresight. They describe her as eager, creative, endowed with spirit and originality, self-reliant, and very strong in advancing her ideas in the face of enormous professional opposition.

Her daughter, Dr. Marianne Eckardt, stated Horney was not one to worry about whether her thoughts would be right. Rather, she permitted her thoughts to form unreined. She was always questioning and working and debating and discussing, and that inner dialogue went on throughout her life and gave her satisfaction. She was a beautiful lecturer. She always had notes, but she never read her lectures, and they always made a circle. She was at home in her creative concepts.

Today I will discuss with you "Violence: The Malignancy of Our Times! is There Hope?" Unlike Horney, I will not be able to speak simply from notes; I do have a written paper. I hope, however, to emulate her creativity, her strength, and to stimulate controversy, thinking, debate, and discussion because, as she said, "Progress and analysis can only be made the hard way - by including ourselves and our difficulties. If we remain static and adverse to changing our theories, we are bound to become boring, barren, and dogmatic." I chose to discuss "Violence: The Malignancy

ELISSA P. BENEDEK, M.D., is Past President, American Psychiatric Association, and Clinical Professor of Psychiatry, University of Michigan School of Medicine. Address correspondence to: 3607 Chatham Way, Ann Arbor, Ml 48105. 
of Our Times! Is There Hope?" from experiences based in my own life and in the lives of some of my patients and in the community around us. First let me say that 1 do not believe we will see a cure in our lifetime to this cancer-the cancer of violence. However, we will hear discussions and debates and we will see increased research, new treatment strategies, and new treatment programs. This can at least give us hope. Later today I will share some thoughts with you about national campaigns I'm involved in to combat violence, particularly violence in the family.

I don't need to tell you-you already know-that violent behavior in America is at an all-time high and seems to be ever increasing. We've always been a violent society; we have the "cowboy" mentality. Violence permeates our vocabulary. I was going to call this talk "Violence: The Call to Arms" until I realized what I was doing. Each day, more and more spectacular acts of violence are reported in the media: a Central Park jogger assaulted, drive-by shootings, babies and mothers dragged from cars. In the past, we believed that violent acts were the problems only of "them" - the poor, the urban, male minorities, school dropouts, persons from broken homes, and emotionally disturbed slum dwellers. These problems didn't belong to us. We now know that violent acts can and do occur in any home in America, in any part of an American city, in the ghetto or an affluent suburban neighborhood. We now know that violence is an illness of epidemic proportions, and as in any illness-from the common cold to AIDS - there is the host, the victim, the virus or bacteria, the victimizer, and a suitable and supportive environment for the illness to flourish. I'll discuss all three today.

The level of violence in our society is so high that we no longer can ignore it. However, our ignorance with regard to causes, prevention, and treatment is vast. As a psychiatrist working in a forensic mental health center, my daily clinical life is filled with the treatment of victims and victimizers. As a person, as a human being, and as a clinician, I abhor violence. Despite the fact that the identification, evaluation, and treatment of violent individuals make up the major part of my professional life, I have never, and will never, become inured or desensitized to violence. Not long ago, in my own community, a sleepy college town, Ann Arbor, a well-known young pediatric ENT surgeon and dedicated family man, Dr. John Kemick, was killed by a mentally ill and seriously deluded patient. The tragic death of this talented physician especially shocked and saddened my community. It made us step away from the normal denial that allows us as citizens, as physicians, as educators, to function on a daily basis without paralyzing fear for our own safety. It sent my community scrambling to understand, to make sense out of nonsense, to make rational from the seemingly irrational, and it prompted me and my colleagues to wonder how vulnerable we are to the rage of our patients. 
Violence is broadly defined as the use of physical force to inflict injury or death upon oneself or another. American society has failed-and American medicine, too-to appreciate the magnitude of the problem that we face every day - in our clinics, on our streets. It is nothing less than frightening. Homicide is the twelfth leading cause of death in the United States, and climbing. In 1988 homicide accounted for more than 22,000 deaths, more in 1990, and even more in 1992.' Homicide is the sixth leading cause of premature mortality-that means years of potential life lost before the age of 65 .

A recent comparison of the international rates of homicide among males ages 15 to 24 in 21 developed countries showed that in the United States the homicide rate was not only the highest among all industrialized nations but it also was 4.4 times higher than the nation next in line-Scotlandand many times higher than the rate of any other developed country. It's much higher than our culturally heterogeneous neighbors to the north and to the south. In adolescents, homicide and suicide are the second leading cause of death. The first is automobile accidents and we don't know how many of those are suicides.

African Americans and other minorities are at a particularly high risk of injury and death due to interpersonal and interfamilial violence. African American males are seven times more likely than white males to die from homicide. Homicide rates are particularly high for young black men, among whom the rates have sharply increased in recent years. The rate of spousal homicide, generally husband killing wife, among African American couples is 8.4 times higher than among white couples, and the rate among Latino couples is higher than that among white couples. Some researchers say poverty accounts for the high incidence of homicide in these populations. Poverty is only one factor. Other factors are the hopelessness, the helplessness, and the constant stress that poverty engenders.

Approximately 20,000 deaths a year are attributed to intentional violence perpetrated by one person against another with 12,000 of those deaths involving firearms. Incidence of domestic violence, homicide, spouse abuse, and child abuse, however, is seriously underreported because physicians don't ask. As you know, males are at a much higher overall risk of injury and death due to interpersonal violence than females, but females are at a much higher risk of nonfatal injuries-injuries due to rape, child sexual abuse, and assault or other forms of domestic violence by intimate partners.

Acts of physical aggression occur in at least one out of every six households among married couples. The rate is said to be one out of two. Of

U.S. Department of Justice: Uniform Crime Report. Federal Bureau of Investigation, Washington, D.C., U.S. Gov Printing Office, 1991. 
these incidents, more than one in three are severe assaults involving such acts as punching, kicking, hitting with an object, or assault with a gun or a knife. Two-thirds of those who say their spouse assaulted them during the year report that they were assaulted more than once and that such violence occurred in the years preceding the survey.

Suicide is the eighth leading cause of death in the United States with rates tripling since 1950 . Suicide rates are increasing particularly among young people ages 15 to 24 . Suicide is now the third leading cause of death in this age group. Further, suicide rates have been consistently higher for whites than for African Americans and American Indians through the years.

Interpersonal violence is a broad term used to categorize any violence, be it physical or mental, between individuals, as opposed to property damage. The relationship between individuals involved in interpersonal violence is an important factor. Violence occurring between individuals who are intimate is usually referred to as "family violence." Violence among family members, too, has reached epidemic proportions. For example, more than 2 million cases of child abuse are reported annually. Most sexual abuse of children is perpetrated by family members. Between 2 million and 4 million women are battered by their spouses every year, and as much as 3 percent of the elderly report being abused.

Until the latter half of this century, the concept of family violence as a national problem did not exist. In October, the New York Times reported that up until then the Catholic Church sanctioned spousal violence. Spousal violence was written into the Bible, and many people assume that if it appears there, it must be acceptable. The church came out against domestic violence at the urging of some of its women members, but it took until the end of the twentieth century.

When particularly brutal cases of abuse were publicized they shocked the public sensitivities, but they were thought to be isolated and committed by a single pathological individual. At the same time mild manifestations of abuse in everyday life were not recognized as abuse but were accepted as normal. Hitting one's wife or using corporal punishment on one's child was considered a man's or a parent's right and sanctioned. Furthermore, it was widely believed that victims of violence brought it upon themselves and thus were as blameworthy or as responsible as the abusers.

The movement to increase awareness of child abuse began in the early 1960 s and was led by professionals who worked with children, including teachers, social workers, and physicians. The movement against elder abuse began in the 1970 s by professionals working with the elderly. The battered women's movement also emerged in the seventies as communitybased shelters and safe homes were founded across the country, and that movement was led by the lay public. Today, the movement against family 
violence in the United States is broad based. It comes from politicians, from sociologists, from lawyers, from judges, from physicians, from psychiatrists, from educators-everybody recognizes that family violence is a problem.

Medicine has, I am happy to tell you, taken a leading role in abolishing family violence by the year 2000 . An impossible goal, you say, but the American Medical Association has spearheaded a campaign to combat it. Anyone, any physician, can join the coalition free, and the AMA is pouring as much money into this campaign as it had into the campaign against tobacco and the campaign to encourage people to wear seat belts. Those campaigns were successful at getting people to change their behavior, and we are hopeful that this campaign will do the same. To give these numbers a human face, let me share with you three clinical examples of violent behavior that I have been involved with recently.

The first is Missy, a 10-year-old child whom I saw about five years ago to determine whether she merited Social Security payments. Missy was a child of poverty, a child of the ghetto who had had more than her share of burdens to carry. Missy's mother was an abuser of a number of substances including alcohol and heroin and had neglected and physically abused Missy. Her father was also a heroin addict. Missy and her two siblings had lived with her parents until the state had terminated parental rights because of the abuse and neglect, particularly the filth in which these children lived and the child beatings that were a part of their daily lives.

When I first saw Missy, I strongly recommended that she begin a course of psychotherapy. Missy was placed by the state with her grandmother and stepgrandfather and once again came to the attention of the state when there were proven charges of sexual abuse on the part of the stepgrandfather. This man, who was a paranoid schizophrenic, had severely and repeatedly sexually abused Missy and her younger siblings. Although he had threatened to kill them if they ever disclosed, they did not keep his ugly secret. After a protracted court battle, the children were placed with other family members and finally with an unmarried aunt who was unable to have children but who desperately wanted them.

Five years after I first saw her, Missy once again appeared with her aunt in my office for evaluation. From the record and from her aunt, I learned that Missy was in a special education program and, although a slow learner, was doing reasonably well in the fourth grade. All the special services she was getting were to be terminated because routine I.Q. tests showed that she did not meet the state's guidelines for retardation. Moreover, the important psychotherapy for the physically and sexually abused child had never been initiated.

Missy still longed for her parents. When I asked her to draw a picture of a family, any family, Missy drew her mother, who by this time was in 
prison; her father, who just had been released from prison; her older brother, who was now living with another relative; her sister, and herself, smiling and happy at a family Thanksgiving dinner, a dinner that was and would remain a pure fantasy.

Missy was one of the saddest children I had ever seen. What will become of her? How will she grow up? Can she escape this cycle of violence, abuse, and neglect? Or will she continue the circle, the cycle? Can we help her? Can we help her aunt or her rebellious sister? I didn't know when I first saw Missy, but I decided that I was going to try, and I'm happy to report that there have been small gains. Getting Missy and her aunt to comply with treatment has been one of the biggest challenges I've had in my professional career, but it's also one of my biggest satisfactions.

Let's now turn to another form of interpersonal violence. l'd like to read portions of a letter from a family physician, Christine Dottier, a letter that she gave me permission to share. When I first read it, this letter shocked me. It came from a middle-class, well-educated woman, a physician. Dr. Dottier says, "I'm a family doctor with a successful solo practice, who was a battered wife for almost 20 years and saw her child being beaten and mistreated. Why am I writing you about this intensely private experience? Because it is silence that keeps women in battering relationships, their own silence and the silence of others, and because physicians can do more to help.

"I was raised in a middle-class home with four children. My parents were and are happily married. There was no violence in my household and rarely any physical conflict. Though it was pleasant not to have dissent, it gave me no chance to learn skills for resolving conflicts in a fair and balanced way. At church I learned that a good Christian turns the other cheek. If I was good, God would take care of me, and I should make myself vulnerable as an act of faith. It was heathen to look out for one's best interest or to fight back. In college I met an appealing young man who was much more outgoing and self-confident than I was. We were both trying to rise above our backgrounds, he toward being well educated, I toward being more aware and responsive to emotion. He talked to me in detail about how out of touch with my feelings my family was. The first time he hit me, he made it seem almost like a learning experience. This is what the world is really about. This is how real people, whole people, express anger. I felt disoriented, caught between a past that said anger didn't exist and the present that said anger and hitting were good, so I acted as if it wasn't real and did nothing.

"The year I was married I went to my parents' home for Christmas, and my grandmother asked me who had been pinching me. I had marks on my arms and legs. I was embarrassed, and I said no one. I thought I was responsible for my destiny, and it was my duty to make this marriage work. 
"In some ways my situation was classic. He would hit me and punch me and then would want to make up-with sex usually. There were stretches of time when things seemed pretty good, and the fact that he had bruised me two months earlier seemed to vanish. Yet he encouraged me to go to medical school. If I thought at all about battered women then, I didn't think it could possibly apply to me, since he supported my professional development. Never mind that he ridiculed my ability to keep a checkbook or that he once woke up the baby in the apartment downstairs with the noise he made by throwing things around, or that one of my friends who witnessed a beating urged me to leave him before he killed me. The thought that I didn't fit every detail of the classic description of the battered wife kept me silent for a long time. Finally, though, I realized that no one situation is classic."

She goes on to say, "Chance helped me leave him. In 1988 my husband beat up my son and called him horrible names on Mother's Day. The symbolism of that day and the incredible injustice that a father should hurt his son on Mother's Day gave me the energy to ask friends for help, to see a therapist, and ultimately to start thinking about separation. My 92-yearold grandmother, the woman who noted that I was pinched, was in the hospital when my parents told her I was separating, and she said she wished my husband were there so she could punch him in the mouth.

"Today, three years after my children and I boarded an airplane to a safe place to visit relatives while a divorce notice was served on my husband, I am finally starting to live a fulfilling and peaceful life."

Dr. Dottier goes on to say, "This time I'm a family doctor who is able to talk to my own patients and others about family violence. Certainly, it's not easy. Sometimes I'm tired or overwhelmed. Sometimes a raw nerve gets touched and I remember my own past too well. Sometimes I just get scared. One woman's boyfriend assured her that he'd kill her and their child if she left him. I put her in touch with the local women's shelter after he blackened her eye. Do I need to be afraid for myself the next time he comes in for a blood pressure check?" But she ends, "Mostly I'm grateful for the help others have given me, and I hope I can do something to pass on the healing."

The third form of violence in the home is elder abuse. The most rigorous study of elder abuse, which is also underreported, reveals that 3.2 percent of elderly persons have been subjected to abuse or neglect. The abuser is generally a relative and in 75 percent of the cases lives with the person he or she abuses. ${ }^{2}$

Recently I saw a lovely elderly Chinese woman who had been physically abused by her physician son because she would not behave in what he 
considered to be a socially appropriate American way with his friends. First, he would exclude her from his fancy dinner parties by locking her in her room when friends came. Later, when she would not remain silent in her room, he beat and abused her. Fortunately her grandchild (his child), an emancipated minor who had been subjected to the same kind of treatment, escaped, fled, and then out of love liberated Grandma. I saw the two of them together. They now live peacefully in an apartment in New York.

Elder abuse, like all the other forms of family violence, seems to have the same kinds of consequences: the same kinds of mental health consequences, lowered self-esteem, isolation from peers, anxiety, depression.

So now l've talked somewhat about the victim. What about the victimizer, the host, the perpetrator? We know a little bit about some pieces of this jigsaw puzzle. Recently a conference to be sponsored by NIMH on the genetic causes of violence was canceled. There seemed to be racial overtones to the conference, and it was considered not "politically correct." So we know little about the role of genes. We know something about neurotransmitters-the neurotransmitters of the violent person are out of whack. Studies of spinal fluid and blood have revealed increases in some transmitters and decreases in others. ${ }^{3}$ We know something about character and personality. DSM III-R gives us a whole list of diagnoses for the violent individual, ranging from antisocial personality to the most serious forms of mental illness. We know something about the demography. We know that most violence is intraracial-that is, African Americans killing African Americans or violently aggressing African Americans. Whites aggressing against whites. We also know that most violent individuals kill a friend or a relative, not a stranger. But we don't understand the lethal combination that makes one young African American man explode while another one goes on to college, even though they may be brothers. Unfortunately there is not enough research being done on the victimizer, the perpetrator.

Finally, the environment. The first environment we have to consider is the family. There are certain common characteristics in violent families. They tend to be isolated from family support and the support of any community organization. They lack a life line; they have no external connections. In addition, since social isolation begets social isolation, parents and children in abusive families are enmeshed and dependent on one another. Consequently, the children have no opportunity to observe or model other family methods of resolving disagreements besides violence.

${ }^{3}$ Tardiff K.: Assessment and Management of Violent Patients. Washington, D.C., American Psychiatric Press, 1989. American Medical Association: Drug Evaluations. Chicago, IL, 1986. 
Alcohol and drug abuse may be prevalent in the abusive family, but not necessarily so. Alcohol and drugs are a handy excuse to allow a violent person to lose his or her inhibition or control. The violent family also is subject to unemployment and economic deprivation. With unemployment more people become crowded in a family home. There is less psychological and physical space, boundaries become blurred, and more violence erupts. At the same time, our American society does much to promote and accept violence, and now I'm referring to the environment at large. We are exposed to an enormous amount of violent behavior on television and in the movies. A Canadian study showed that a community in which children were deprived of television for three years was peaceful. When the kids had access to television again after a period of deprivation, the violence among them increased by 160 percent in one month. The images in magazines and other popular culture genres linking sex and violence promote violence as well. Our culture not only stresses values of toughness, excitement, and pleasure-seeking, but also glorifies them.

I believe that the ready availability of weapons promotes violence in those who believe they need to pack a pistol to even things up or to express their aggression. I am particularly concerned because lethal weapons are proliferating in this, the final, decade of the twentieth century. The easy accessibility of lethal weapons in combination with society's image of violence as a way to solve problems may mean that we will have an even more violent environment in the next century if we don't do something soon. Herb Cleaver, whom many of you know, talks about the fact that we now have weapons that are newer and better available to kids than Saturday night specials. They have access to uzis and similar weapons that can deliver more firepower than most weapons previously in circulation, and they require little or no experience to use effectively. Cleaver adds that adolescents seem ready to turn to these weapons as a way to resolve quarrels more so than formerly. And, he says, many of these youngsters have no respect for their own lives, let alone the lives of others. To them life is cheap, even their own. They often have no vision of the future, and they do not fear losing their own lives for they feel as though they will not lose much.

The complexity of the causes of violence and violent injuries has several important implications. There is no single comprehensive solution that will prevent all violence or even all incidents of a certain kind of violent behavior. Think for a moment about gangs who are interested in obtaining drugs. Increasing police efforts and building more jails, as some people have suggested, to suppress gangs might contribute to preventing one gang's fly-by shooting, but they don't address any of the other contributing causes that bring about gangs: lack of self-esteem, feelings of not belonging, and a 
lack of opportunities for jobs that build self-esteem and help adolescents not only resist the world of drugs but also keep them away from violent neighborhoods.

I believe we need to take steps to decrease the cultural acceptance of violence by discouraging corporal punishment in the home and in the school. You would be amazed at how many schools in the United States still have a paddle and encourage its use. I also believe that we should abolish capital punishment by the state because this is a way the state models and sanctions violence. The progression of learning is obvious. The state provides a model for the family, the family a model for the child. Capital punishment and state-supported corporal punishment in the schools convey implicit and explicit messages to the family.

Furthermore, we need to discourage the presentation of violence by role models in all media forms, but especially television, and encourage the presentation of positive nonviolent role models. Television, movies, the arts, and other forms of popular media can serve a prosocial role.

We know from experience that the portrayal of violence in the media not only influences those individuals who are otherwise at risk but creates a risk itself. I can't tell you how many people I have seen clinically who told me, "I first thought about doing this [act of violence] after I watched a television program." I'm not going to talk about institutionalization and the problems violence in the media creates for mentally ill individuals who sometimes become violent as a last cry for help.

Finally, physicians and educators must step forward and help establish broad-based community coalitions to enhance the awareness of violence of all sorts. We must assume the leadership role that is incumbent upon us as professionals, as human beings, as citizens of this country. As health professionals, we must make every effort to end violence wherever it occurs. Our children, our wives, our husbands, our friends must be free to live their lives, free from violence inside and outside the home. Our awareness, our intolerance of violence, and acts of intervention can greatly diminish the license in this country to commit violence. We can and we must make a difference, both as individuals and collectively in our organizations.

Well, I've told you there is hope and I truly believe there is hope, but it's only through constant vigilance and attention to the precursors of violence in ourselves, in our families, and in our communities that we can hope to begin social policies of primary prevention. By our own conducts we must make gentleness a virtue. We must see violence as the ultimate human degradation. We must learn and teach to resolve disputes by reason, by compassion, by the democratic process. Violence must be recognized as the ultimate despot, driving us to more and more force, continuing a circle. 
We worry about bequeathing the national debt to our children; we must worry even more about bequeathing this national ethos and culture to our children because, like any epidemic, like any cancer, if we fail to take action, our children and our society are at great risk. But, I believe if we act conservably, as citizens and professionals, we will eventually find many cures and defeat this disease. 